\title{
$\mathrm{p}$-ニトロアニリン飽和蒸気のPETフィルム への平衡収着と $\mathrm{p}-\mathrm{NA}$ クセシビリティー
}

\author{
福井大学工学部 清水 融 - 清水和 文 $^{* 1}$ \\ 足立晏久 ${ }^{* 2}$. 堀照夫
}

\section{EQUILIBRIUM SORPTION OF p-NITROANILINE \\ FROM THE SATURATED VAPOR PHASE \\ ON PET FILM AND p-NA ACCESSIBILITY}

\author{
By Toru Shimizu, Kazufumi Shimizu ${ }^{* 1}$, \\ Yasuhisa Adachi ${ }^{* 2}$ and Teruo Hori \\ (Faculty of Engineering, Fukui University, \\ Bunkyo 3-9-1, Fukui 910, Japan)
}

\begin{abstract}
The standard heat of sorption of dye on polymer can be estimated from the temperature dependence of the equilibrium dye sorption by means of vapor phase dyeing. However, for the cases that the significantly large amounts of dye are sorbed on the polymer, the accurate estimation can not be done, because the high sorption causes the irreversible structure change in polymer.

In this study, the "p-NA accessibility" was defined to know the extent of such irreversible structure change caused for the system of disperse dye - PET film. It was found that the PET films dyed below $85^{\circ} \mathrm{C}$ from the vapor phase had the same (constant) p-NA accessibility because of small amounts of dye sorption, while above $90^{\circ} \mathrm{C}$ p-NA accessibility increased with increasing the amount of dye sorption. It could be recognized that the p-NA accessibility was closely related to the polymer density, the intensity of small angle scattering of X-ray and so on, which could be also represented the structure change of polymer.

Furthermore, it was shown that the heat of sorption corrected with p-NA accessibility were agreed with those obtained for the regions, in which no structure change occurred.
\end{abstract}

(Received April 15, 1985)

\section{1. 緒言}

染料一織維間の結合エネルギーを求めるこ上は染色化 学の基醍課題の1つである。染色の多くは水溶媒を用い て行なう。したがって水溶液から繊維への染料の平衡収

*! 現在の所属：住江織物株式会社, テ 558 大阪市住吉 区墨江中 2-18

Present address: Suminoe Orimono Co. Ltd., Suminoe naka 2-18, Sumiyoshi-ku, Osaka 558

${ }^{* 2}$ 現在の所属：東洋紡績株式会社， $\mathrm{T} 530$ 大阪市北区 堂島浜 2-2-8

Present address: Toyobo Co. Ltd., Dojimahama 2-2-8, Kita-ku, Osaka 530
着量が測定され多くの研究者らにより標準親和力が算出 された。そして，それらの温度依存性から標準染色熱が 求められ、これらの值加ら染料一織維間の結合の強さ, 粘合様式などが推測された。しかし，標準染色熱の中に

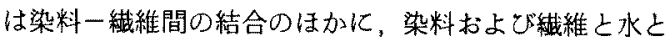
の結合と離脱また水構造の変化などが含まれ，ての值か ら染料一纎維間の結合を考察するのは複雑である。

これに対し，気相染色の平衡収着量加ら求めた標準収 着熱は染料および繊維と他の気体間の相互作用が算で きるので，容易に染料一䄉維間の結合についての情報を

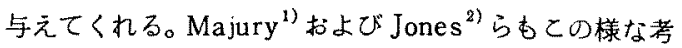
えで気相染色により分散染料およびそのモデル化合物の 
アセテート等への平衡収着量を求め, 収着熱を算出した。 筆者ら ${ }^{3)}$ 6同様な考えで分散染料の飽和蒸気よりポリ エチレン・テレフタレート (PET)フィルムへの平衡収 着量を求め，収着熱算出し，乙れを染料の开華熱と比 較し染料－PET間の結合について考察した。しかし， その後自己の研究結果について疑問を抱いた。その1つ は PETフィルムに多量の染料加収着した場合、フィル ムは膨張し構造変化が起こる恐れがある。もしかかる変 化が起てった場合，てれを無視して取着熱を算出したよ きの譟差についてである。

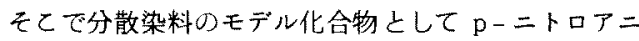
リン(p-NA)を選び，との飽和蒸気のPETフィルム人 の収着について詳細に椮討した。その結果，p-NAを多 量收着するとPETフィルムは不可逆的構造变化を起こ し，との様な収着結果から算出した取着熱は正しくない ことを認めた。をしててのp-NAの気相収着を利用して PETの非晶領域の変化を定量的に求める方法を見出し, この值を $\mathrm{p}-\mathrm{NAアクセシビリティー}(\mathrm{p}-\mathrm{NAaCc})$ と名付 けた。をして p-NAaccを用いて多量収着あるいは結晶 化などによる PET の非晶体積変化を補正し，より正確 な収着熱を算出することが出来た。以下てれらについて 報告する。

\section{2. 奏蹹試料および方法}

\section{1 使用したPETフィルム}

使用したフィルムを表1に示す。

No. 2 はUフィルムを $30^{\circ} \mathrm{C}$ のアセトン溶液中に $24 \mathrm{~h}$ 浸漬後，常温で $24 \mathrm{~h}$ 乾燥したフィルムで，このアセト ン処理によりUフィルムはそれを $120^{\circ} \mathrm{C} 、 2 \mathrm{~h}$ 自由長乾 熱观理したフィルムとほぼ等しい結晶化が起こるととを X線回折によって確加めた。 No.3はUを手廻し延伸器 に上り $65^{\circ} \mathrm{C}$ の水中で倍率 4.0 , 速度 $50 \% \mathrm{~min}^{-1}$ の条件で 一軸延伸したもので，との延伸で配问性が著しく向上し たことをX線回折より認めた。No.4,5および6はD， M执よび Tを夫々No. 2 と同じ条件でアセトン処理して 試料とした。このアセトン処理でNo.4は密度が增加し

Table 1 PET films used in the current study.

\begin{tabular}{c|c|l|c|c|c}
\hline No. & Code & Property(Treatment) & Manufacturer & $\begin{array}{c}\text { Density } \\
\text { g.cm-3 }\end{array}$ & $\begin{array}{c}\text { Thickness } \\
\mu m\end{array}$ \\
\hline 1 & U & Undrawn PET film & Teijin & 1.348 & 40 \\
2 & U-AC & Acetone treated U film & & 1.361 & \\
3 & D & Uniaxial Drawn U film & & 1.358 & \\
4 & D-AC & Acetone treated D film & & 1.368 & \\
5 & M & Biaxial Drawn film & Du Pont & 1.398 & 12.5 \\
6 & T & Biaxial Draun film & Teijin & 1.407 & 12.5 \\
\hline
\end{tabular}

たが、MおよびTは变化しなかった。またMはトランス 值（IR $973 \mathrm{~cm}^{-1} / 794 \mathrm{~cm}^{-1}$ 吸光度比）1.80 1.90および Tは1.92 1.99の値の範囲選択し試料に供した。なお 密度は $n$-ヘプタン一四塩化炭素により作成した密度勾 配管を用いて $25^{\circ} \mathrm{C} て ゙$ 測定した。また式（2）の結聂化度 は密度より算出した。

\section{2 使用薬品}

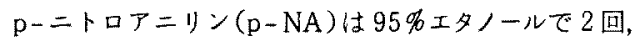
水で 2 回再結晶し精製した。 m. p. $147.5^{\circ} \mathrm{C}, \rho=1.424$ $\mathrm{g} \cdot \mathrm{cm}^{-3}{ }^{4}$, 蒸気圧 $P$ は $A=4924.7, B=11.593$ 。

\section{3 気相染色法 (封管染色法)}

$21 \times 200 \mathrm{~mm}$ 試験管の下半分の内壁に染料のアセトン 溶液の必要量を均一に付着させ，アセトンを蒸発させた 後，ホルダーに固定したPETフィルムを捕入し，管内 を窒菜ガスで置換後，減左下 $(2 \sim 3 \mathrm{mmHg})$ で密封した。 この管を所定㵊度の油浴恒温槽中に浸清し，平衡に到達 するに十分な時間放置した後，管より PET フィルムを 取り出し，フィルムをmークレゾールに溶解し比色法で p-NAの収着量を求めた。

$\mathrm{p}$-NAaccの測定には染色フィルム約 $10 \mathrm{mg}$ を $25 \mathrm{C}$ のア七トン $25 \mathrm{ml}$ で $3 \mathrm{~h}, 25 \mathrm{ml}$ で $4 \mathrm{~h}$ 扰よび $25 \mathrm{ml}$ で 15 $\mathrm{h}$ 計 3 回抽出し，乙れらの抽出液を計 $100 \mathrm{ml}$ とし, 此 色法で収着舅を求めた後，抽出フィルムを気相染色法と 同じ方法で, $\mathrm{p}$-NAを用い $85^{\circ} \mathrm{C} ， 48 \mathrm{~h}$ 染色し，その収 着量を求め, その值 $(\mathrm{g} / 100 \mathrm{~g})$ を-NAacc 值とした。

\section{3. 結果および考察}

\section{1 - NA 的和蒸気のPETフィルムへの平衡} 収着量および収着に伴うPETの構造変化

各種温度のp-NA 飽和蒸気中で各種 $\mathrm{PET}$ フィルム の平衡取着量を测定した結果は図1に示す。

染色温度の上昇之共に平衡取着量は增加する。これは 温度上开に伴い $\mathrm{p}-\mathrm{NA}$ 飽和蒸気圧が増加するためであ る。そして密度の大きなフィルムほど収着量は低くなる 傾问がみられる。製造直後のTフィルムは 性を示していたが，製造 8 年後に使用したので経時変化 により結晶化加起こり密度が增加し ていた。そして非昆領域内でポリマ 一間の結接点の増加なども起とり安 定化し，そのため高温側での収着量 の低下6目立ち，またより高温での 染色 $\left(150^{\circ} \mathrm{C}\right)$ でも他のフィルムと異 なり融解が起こらない。

$\mathrm{p}$-NAを収着したしれらU一Ac およびD-Acフィルムからアセトン でp-NAを抽出した後，をれらの物 


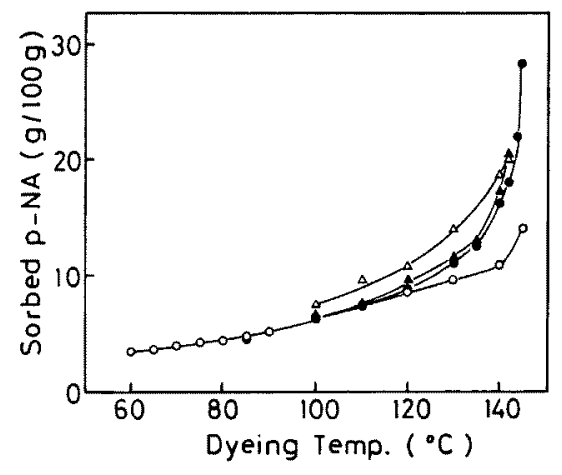

Fig. 1 Equilibrium amounts of p-NA sorbed on various $P E T$ films $(\triangle:$ U-Ac, $\triangle$ : D-Ac, - $\mathrm{M}, \mathrm{O}: \mathrm{T}$ ) from saturated $\mathrm{p}-\mathrm{NA}$ vapor.

Table 2 Changes of micro-structure in film with temperature of heat treatment of dyeing (U-Ac and D-Ac)

\begin{tabular}{|c|c|c|c|c|}
\hline \multirow{2}{*}{ Mreatment } & \multirow{2}{*}{ Temp. $\left({ }^{\circ} \mathrm{C}\right)$} & \multicolumn{2}{|c|}{ Crystalline region } & \multirow{2}{*}{$\begin{array}{l}X \text {-ray(S.A.) } \\
\text { Intensity }\end{array}$} \\
\hline & & IR & Density & \\
\hline \multirow{2}{*}{ Dry Heat } & $100-160$ & & & \\
\hline & $160-220$ & & & \\
\hline Dyeing & $120-140$ & & & \\
\hline
\end{tabular}

性変化を調べた。同時にブランクとしてU一的および $\mathrm{D}-\mathrm{Ac}$ 各種温度で乾熱処理した試料の物性変化も測定 し，それらの結果を此較するため表 2 で定性的に示した。 乾熱処理およびp-NA取畕(染色)フィルムは処理温度の 增加と其に結晶化がより強く起こるとよが IRトランス值 および密度の測定結果から諗められだ。X線小角散乱强 度は結晶拈よび非晶領域の密度差に関連しているが，こ の変化が染色フィルムでは処理温度が低いにあ拘わらず， $160^{\circ} \mathrm{C}$ 以上の乾熱処理と同样な強度㳅化を示している。 乙れは熱の作用のはか加 加わったためと考えられる。さらにこれらの試料に対し p-NAacc 测定した結果を図 2 に示す。乾熱好理では $\mathrm{U}-\mathrm{Ac}$ およひ D-Ac 共に $160^{\circ} \mathrm{C}$ 付近にp-NAacc の極小 值が生じている。これは PET 織維の乾熱好理しその染 色性との関係を調べた Marvin ${ }^{\circ)} の$ 結果と類似した形で ある。一方，染色試料では $160^{\circ} \mathrm{C}$ 以上乾熱処理で生ず る p-NAacc の增加之同じ関係が殷的られ，X線小角散 乱強度の変化とも等しい関係にある。

3.2 p-NAアクセシビリティー(p-NAacc)

因 2 亿示吉如 $<85^{\circ} \mathrm{C}$-NA飽和蒸気のPET基質への 平衡収着量の傎は PET の構造変化を鋭敏に反映し，之 の非罩領域の状態を推測する1手段になると考えられる。

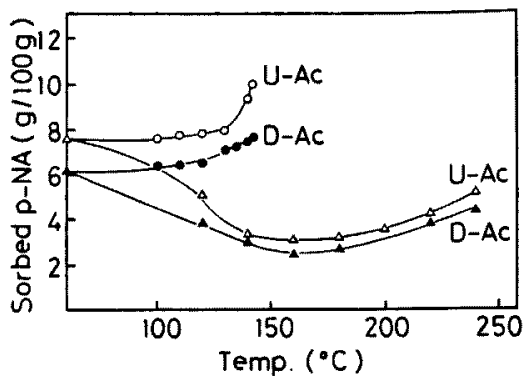

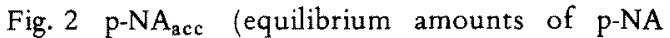
sorbed at $\left.85^{\circ} \mathrm{C}\right)$ of various PET films. $O(U-A c),(D-A c)$ : for films extracted with acetone after dyeing with p-NA $\triangle(\mathrm{U}-\mathrm{Ac}), \Delta(\mathrm{D}-\mathrm{Ac})$ : for films treated with acetone after heat treatment

Table 3 Experimental error of equilibrium amount of sorption and reproducibility of the sorption data for re-dyeing after acetone-extraction.

\begin{tabular}{|c|c|c|c|c|c|c|}
\hline $\begin{array}{l}\text { Dyeing } \\
\text { Temp. } \\
\left(^{\circ} \mathrm{C}\right)\end{array}$ & $\begin{array}{l}\text { Sorbed } \\
\mathrm{p}^{-\mathrm{NA}} \\
(\mathrm{g} / \mathbf{1 0 0 \mathrm { g } )}\end{array}$ & $\begin{array}{l}\text { Er. } \\
( \pm 8)\end{array}$ & $\begin{array}{l}\text { sorbed } \\
\mathrm{g}-\mathrm{NA} \\
(\mathrm{g} / 100 \mathrm{~g})\end{array}$ & $\begin{array}{l}\text { Et . } \\
( \pm 8)\end{array}$ & $\begin{array}{l}\text { Sorbed } \\
\text { p-NA } \\
(g / 100 g)\end{array}$ & 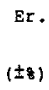 \\
\hline 85 & 4.80 & 1.2 & 4.87 & 1.1 & $\rightarrow 4.77$ & 0.9 \\
\hline 80 & 4.51 & 1.4 & 4.45 & 0.6 & & \\
\hline 65 & 3.66 & 1.9 & & & & \\
\hline 60 & 3.48 & 0.8 & 3.42 & 0.4 & & \\
\hline
\end{tabular}

そこで，このp-NA気相染色条件下でPET 基質は構 造変化を起こさず，また平衡収着量の值も再睍性がある かをТフィルムを用いて調へた。その結果を表 3 亿示す。

$85^{\circ} \mathrm{C}$ 気相染色の結果はアセトン抽出後再染色の工程 を2回繰返したが，収着量は $4.80 \mathrm{~g} / 100 \mathrm{~g} \pm 1.5 \%$ で一 致を見た。また $85^{\circ} \mathrm{C}$ 以下の低温での再染色結果む一致 觉た。

これらの結果から p-NA 飽和蒸気による染色では 85 Cまを゙Tフィルムでは不可逆的構造変化は生じないこと を認めた。無定型PETの $T_{\mathrm{g}}$ は $80^{\circ} \mathrm{C}$ 付近であり, $\mathrm{p}-\mathrm{NA}$ の如き可塑剤が加わると $T_{\mathrm{g}}$ 低下が予想されるが，Uフ ィルムでは $85^{\circ} \mathrm{C}$ 染色間に結晶化が起こり, p-NAacc は 低下した。しかし，U-Ac，D-Ac および ィフィムで は $85^{\circ} \mathrm{C}$ p-NA収着量と $\mathrm{p}-\mathrm{NAacc}$ は一致した值が得ら れた。

D-Acフィルムを各種温度で2時間乾熱処理した試料の X線小角散乱強度と $85^{\circ} \mathrm{C}$ D $-\mathrm{NAacc}\llcorner の$ 関係を示すと 図3の如くになる。160兄までの乾熱好理ではp-NAacc の低下は著しいが, 散乱强度の変化は極好少ない。一 


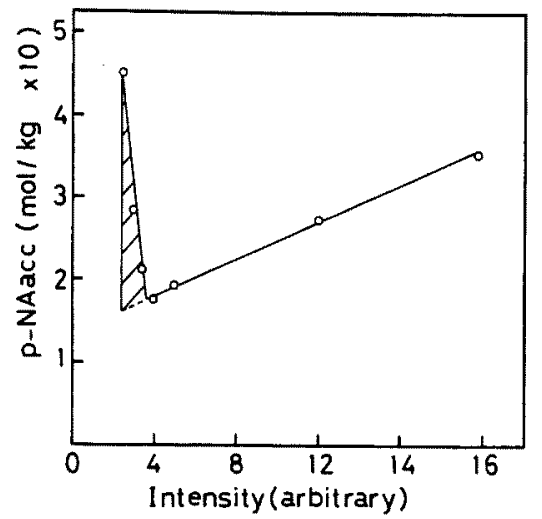

Fig. 3 Relation between intensity of small-angle scattering and p-NA accessibility.

方密度は温度の上昇と共に增大し強く結晶化が起こるこ 上を示しているが，ての低温領域での結晶化は同時に非 晶領域の緻密化あるいはポリマー間の結接点の增加を生 じ，てれが p-NAacc の低下と強く結びついているため と考えられる。更に $160^{\circ} \mathrm{C}$ 以上の乾熱处理では，密度は さらに增加し結晶化が増大するにも拘わらず，散乱強度 は增大し p-NAaceも增加する。乙れは結晶領域之非晶 領域間の密度差の增大，すなわち，非晶構造の疎化が生 じたためてれに伴い p-NAacc 李增加したものと若えら れる。なお酒井ら ${ }^{6)}$ の独創的研究によると，高温度の熱 処理で PET は分散染料の収着量を增加するが，乙れは 結晶のサイド表面への吸着の增加によると説明している。

以上より $\mathrm{p}-\mathrm{NAacc}$ は PET の非晶領域の変化を知る 尺度として役立つてとが認められた。

\section{$3.3 p-N A$ 蒸気のPETフィルムへの標準収着 熱}

p-NA 蒸気のPET 基質への収着挙動は低温度，低濃 度収着の範囲ではHenry 則が成立する。

Majury ${ }^{1}$ はアセテートフィルムへの p-NA 蒸気の収 着について，等温収着線は原点を通る直線となり Henry 則の成立を認めている。しかし， $120^{\circ} \mathrm{C} の \mathrm{p}$-NA飽和蒸 気あるいは飽和に近い蒸気加らの平衡収着量は直線とな らず，特倍高温ではフィルムが著しく変形し，収着量が 異常に大きくなった。また Jonesららばはゾベンゼンを 含む 5 種の分散染料蒸気のアセテートフィルムへの等温 収着曲線は $\mathrm{p}$ ーアミノアゾベンゼンを除き，Henry 則の 成立を認めた。著者ら゙は $\mathrm{p}$ ーアミノアゾベンゼン蒸気の PETフィルムへの等温収着曲線が飽和蒸気まで Henry 則に従うことを認めた。したがって p-NA 飽和蒸気の PET フィルムへの平衡収着は，むし，1）飽和蒸気が 単分子状態であり，2） PETフィルムの非晶領域に分
子状に分散し吸着され，3）収着によりフィルム構造に 不可逆的变化が起とらず，4）気相染色間にフィルム表 面にp-NAの凝縮などが生じなりれい゙ Henry 則に従う であろう。1)について小島 ${ }^{8)}$ (分散染料の飽和蒸気住単 分子分散であることを証明し，2)に执いて筆者 ${ }^{8)}$ は DSC 測定によりp-NAのPETフィルムへの溶解度は $10.4 \mathrm{wt} \%$ であり，単分子状態で非晶領域に吸着している ことを認めた。したがって本実験の平衡収着量は $140^{\circ} \mathrm{C}$ 染色以下では溶解度以下であり，単分子状態で非晶領域 に吸着していることを認めた。それ故，3）拉よぴ4)の 現象が起こらなりれば $\mathrm{p}-\mathrm{NA} の$ 各温度の䭒和蒸気とその 平衡収着量との関係は原点を通る直線の等温収着曲線上 にある亡考えて良い。従って分配係数 $K$ は次式で求めら れる。

$$
\begin{aligned}
& K=[D]_{\mathrm{f}} /(D]_{\mathrm{g}} \cdot 1 / v_{0} \\
& v_{0}=1 / o_{\mathrm{a}} \cdot(1-X)
\end{aligned}
$$

ここで $(D)_{\mathrm{g}}$ は飽和蒸気濃度 $\mathrm{mol} / l,[D]_{\mathrm{f}}$ は平衡収着 量 $\mathrm{mol} / \mathrm{kg} ， v_{0}$ はつィルム $1 \mathrm{~kg} に$ 含まれる非晶領域の 体皘 $l / \mathrm{kg}, X$ は結晶化度拈よび $\rho_{\mathrm{a}}$ は非晶領域の密度 $1.335 \mathrm{~g} / \mathrm{cm}^{3}$ である。PETのXは測定法により著しく 值が異なり，どの測定法によるかが問題であるが、本研 究は比重法を用いた。そして標準親和力 $\Delta \mu_{\text {sorp }}^{\circ}$ および 標準収着熱 $\Delta H_{\mathrm{sorp}}^{\circ}$ は次式加ら求められる。

$$
\begin{aligned}
& -\Delta \mu_{\text {sorp }}^{\circ}=R T \ln K \\
& -\Delta H_{\text {sorp }}^{\circ}=\frac{d\left(-\Delta \mu_{\text {sorp }}^{\circ} / T\right)}{d(1 / T)}
\end{aligned}
$$

各種温度の $\mathrm{p}-\mathrm{NA}$ 飽和蒸気で染色した Tフィルムの結 果をもとに式(3)より $\Delta \mu_{\text {sorp }}^{\circ}$ を求如, さらに式 (4)に 徉ってーJ $\mu_{\mathrm{sorp}}^{\circ} / T-1 / T$ の関係をプロットすると図 4

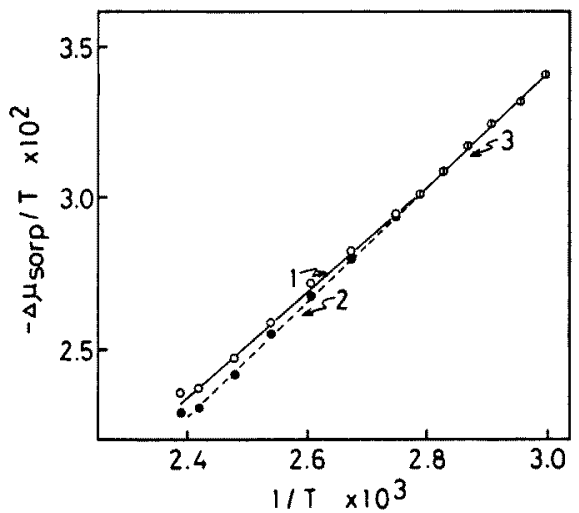

Fig. 4 Correction of v-term in relation between $-\mu \% T$ and $1 / T \quad(O$ : no correction, correction with $\mathrm{p}-\mathrm{NA}_{\mathrm{acc}}, \Phi$ : no change of v-term) 


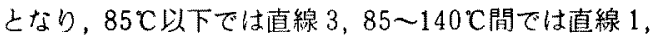
さらに $145^{\circ}$ Cはこの線よりはずれる。乙㧈ら各種温度の 平衡収着フィルムおよびその染色之同温，同時間のブラ ンク乾熱処理フィルムの p-NAaccを測定した結果は図 5である。

収着フィルムもブランクフィルムも $85 \mathrm{C}$ 以下では等 しいp-NAaccを示すが，90以上では収着フィルムの p-NAacc は温度上异と共に增大した。一方ブランクフ ィルムでは $120 \mathrm{C}$ 以上で温度と共经減少する。後者は熱 効果による結晶化が原因であり，前者は $\mathrm{p}-\mathrm{NA}$ の収着量 の增加でフィルムが殸張し，その非晶領域に不可逆的変 化が生ずるためであ万う。したがって式（1）中のv。は 非晶体積変化を補正せ齐ばならず，その補正式として，

$$
v_{\text {correct }}=v_{0} \frac{\mathrm{p}-\mathrm{NAacc}\left(t^{\mathrm{C}} \mathrm{C}\right)}{\mathrm{p}-\mathrm{NAaCc}\left(85^{\circ} \mathrm{C}\right)}
$$

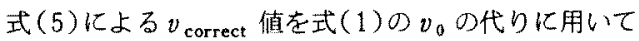
$K$ および $\Delta \mu_{\text {sorp }}^{\circ}$ を再計算し，その值を用いてプロット した結果が図 4 の黒丸点であり，直線 2 が得られた。収 着により PETに構造变化が起こらない範国内での直線 3 より求めた $\Delta H_{\mathrm{sorp}}^{\circ}$ は $-18.7 \mathrm{kcal} / \mathrm{mol}$ であり，不可逆 的構造変化を含む直線 1 より求加 $\Delta H_{\text {sorp }}^{\circ}$ はー16.7 $\mathrm{kcal} / \mathrm{mol}$ である。これに対し，直線 2 は直線 1 のほほ 延長上にあり，一 $18.4 \mathrm{kcal} / \mathrm{mol}$ となった。したがって この補正法の有効性を認めることができた。しかし 145 Cの結果に対しては補正できなかった。ジメチルホルム アミドなどの容剤処理で PET 基質は膨張しボイドが形

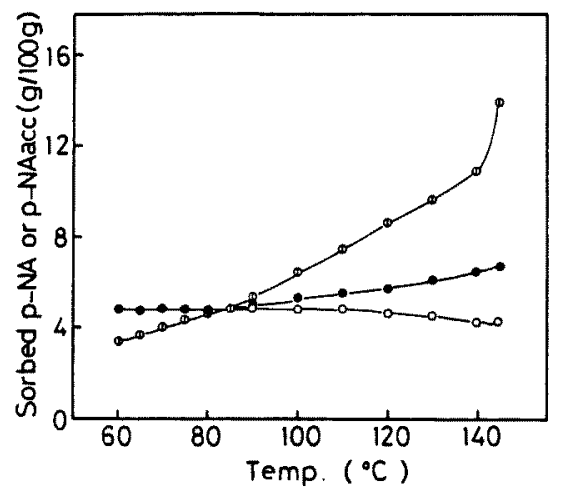

Fig. 5 Equilibrium amounts of p-NA sorbed at various temperatures and their $\mathrm{p}-\mathrm{NA}$ accessibility.

(D) : amounts of p-NA sorbed by vapor phase dyeing at various temperatures

- : $\mathrm{p}-\mathrm{NA}_{\mathrm{acc}}$ of film extracted with acetone after dyeing

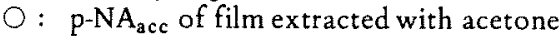
after heat treatment (Blank Test)

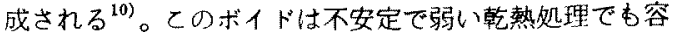
易に崩買することを筆者らは認めている。145 C 0 如き 極めて多量のp-NA収着によってい同様なボイドが形成 されそしててのボイドはアセトン抽出の際に一部崩壊 するため $\mathrm{p}-\mathrm{NAacc}$ が小さくなったため上考えられる。 すなわち，ア七トン処理で構造変化を起こす様な特殊 PET 試料，例えばUフィルムあるいはボイドが形成し た極めて非晶構造の不安定な試料などには p-NAacc に による補证は利用できない。

なお筆者らは各種温度の封管染料で $85^{\circ} \mathrm{C}$ の-NA 収 着量 $(4.80 \mathrm{wt} \%)$ 上り少量の染料収着を示す 1 ーアミノア ントラキノン(1-AAQ)，およびより多量の収着を示す $\mathrm{p}$ ーアミノアゾベンゼン $(\mathrm{p}-\mathrm{AAB})$ について同様な方法 で実験を行なった。染色物に対してp-NAacc 測定し， てれらの染料にも $\Delta H_{\mathrm{sorp}}^{\circ}$ の算出に対して $\mathrm{p}-\mathrm{NAacc} に よ$ る $v$ 補正が有効であるかを検討した。

1-AAQ 染色物に対する $\mathrm{p}-\mathrm{NAacc}$ は染色温度の上开 上共に减少した。てれとブランク染色物に対する比較か ら，とのp-NAacc の減少は熱によるフィルムの結晶化 のために生じた減少であり，染料の収着には無関係で あるととが判明した。そしてp-NAaccによって式 (5) に従い, $v$ を補正して求めた収着熱 $(-23.02 \pm 0.02 \mathrm{kcal}$ $/ \mathrm{mol})$ は補正女ずに求めた值 $(-23.40 \pm 0.04 \mathrm{kcal} / \mathrm{mol})$ 上誤差範囲で一致している。使用したフィルムは比較的 構造が安定したフィルムであったため，染色間の熱の影 響による結晶化も少なく，ての程度のアクセシビリティ 一の変化では $v$ 補正の必要がないととを認めた。

一方，p-AAB 染色物に対する $\mathrm{p}-\mathrm{NAacc}$ は染色温度 の上昇之共に增加した。しかし，ての增加率は $\mathrm{p}-\mathrm{NA} の$ 収着量に対するp-NAacc の增加率の約 60\%であった。 多量収著に伴う p-NAacc の增加率は染料の種類によ。 て異なるのかあ知れない。そしてその理由は別として， この現象に対し 2 種の仮定ができる。その1)，p-AAB の多量収着に上る不可逆的構造変化で增加した領域に対 して，p-NAはその1部分にしか収着できない。その2）, 同一収着量で比べると，p-AABはp-NAよりも不可逆 的满造変化を起としにくい。

そして，この 2)の仮定の場合には p-NAaccによる $v$ 補正は収着熱の算出に有効である。 $v$ 補正した収着熱 はー20.26士0.04 kcal $/ \mathrm{mol}$ であるのに対し，補正しない 值はー18.95 $0.03 \mathrm{kcal} / \mathrm{mol}$ であり， その差 $1.3 \mathrm{kcal} /$ $\mathrm{mol}$ は誤差範囲以上の異なりである。

しかし，1）の場合ではこのv補正では未だ不十分であ り，实際の収着熱は上記の補正值上り更に大きな值であ ることが予想される。こして正確な補正には $\mathrm{p}$-AABacc によるv補正が必要加手知れない。筆者らは現在ての点 
に関して、これ以上の考察は出来ず，実験上共に検討中 である。従って p-NA以外の他染料㳊よる多量収着に対 しp-NAaccで $v$ 補正して算出した収着熱の值の妥当性 は不明である。

\section{4. 結 論}

分散染料によるPET の気相染色から収着熱を求め， 染料一PET 基犋間の結合任関する知見を得る目的で研 垫を行なったが，染料の収着量が多くなるとPET 基質 亿满造変化が起とり，収着熱を正しく求めることが出来

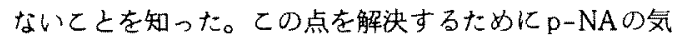
相染色を詳細に検討した。

各種PETフィルムを各種温度のp-NA 館和蒸気で気 相染色し、フィルムに p-NAを平衡収着させ，とれをア セトンで抽出後。再度フィルムを $85^{\circ} \mathrm{C} p-\mathrm{NA}$ 飽和蒸気 で再染色した。その結果の収着量の值および抽出したつ ィルムの密度，IR，DSC およびX線小角散乱強度など の物性の測定結果から, 90 C以上の染色温度では p-NA が多量収着するため PET フィルムに不可逆的構造変化 が生ずることを見出した。そして $85^{\circ} \mathrm{C}$ p-NA 飽和蒸気 の平衡収着量は PET の非晶領域の変化を知る尺度とな るととを見出し，乙れを $\mathrm{p}-\mathrm{NAacc} と$ 名付けた。そして 染色の結果多量収着によって PET に構造変化が生じて 6，p-NAaccを測定し，非晶体皘の変化を補正するこ とにより、より近似な収着熱を算出する方法を見出すこ
とが出来た。筆者らは，乙れを応用して先に報告した分 散染料の PET 基質への收着熱 ${ }^{3)}$ について再検討を加え る予定である。

付 記: 本研究の一部は昭和 57 年 10 月の䄉維学会秋 期研究発表会(信州大学)において発表した。

\section{文献}

1) T. G. Majury; J. Soc. Dyers Col., 70, 442 (1954), 72, 47 (1956)

2) F. Jones and R. Seldon; Text. Res. J., 34, 373 (1964), 35, 334 (1965)

3）清水 融; 日本学術振興会 120 委員会年次報告, 17，60（1965). 喜多村一夫; 新染色加工講來，4, (学振 120 委員会編)，p. 106, 共立出版社 (1971)

4) E. C. Ibe; J. Appl. Polymer Sci., 14, 837 (1970)

5) D. N. Marvin; J. Soc. Dyers Col., 70, 16 (1954)

6) T. Sakai, K. Miyasaka and K. Ishikawa; Sen-i Gakkaishi, 34, T-475 (1978)

7) 清水 融, 小嶋正雄, 堀照夫, 木村光雄; 福井 大学工学部研究報告, 33，63(1985)

8) 小島 弘; 織学誌, $26,530(1970)$

9）清水融，張為象，堀 照夫; 第 10 回䄉維連合 研究発表会講演要旨集, p. 54 (1984)

10）渡辺孝宣, 三好政和, 高橋利祜, 辻本石雄; 瀻学 誌, 33, 185 (1977) 